\title{
Analisis Kebutuhan Pengembangan Usaha dan Strategi bagi Jalan Tol Bali Mandara
}

\author{
Analysis of Business Development Needs and Strategy for Bali \\ Mandara Toll Road
}

\author{
Yoga Pradana $^{1, \mathrm{a})}$, Endo Petakasari ${ }^{2, \mathrm{~b})}$, Rita Sri Jayanti ${ }^{2, \mathrm{c}}$, Ria Asih Aryani Soemitro ${ }^{3, \mathrm{~d})}$, \\ \& Hitapriya Suprayitno ${ }^{3, e)}$ \\ 1) Biro Perencanaan Anggaran dan KLN, Sekretariat Jenderal, Kementerian PUPR \\ ${ }^{2)}$ Balai Besar Pelaksanaan Jalan Nasional VIII, Direktorat Jenderal Bina Marga, Kementerian PUPR \\ ${ }^{3}$ Departemen Teknik Sipil, Institut Teknologi Sepuluh Nopember (ITS), Surabaya
}

Koresponden : a)dana.yogapradana@gmail.com, ${ }^{b}$ endo.petakasari@gmail.com, c)ritasrijayanti@gmail.com, ${ }^{\mathrm{d})}$ ria@ce.its.ac.id, dan ${ }^{\mathrm{e})}$ suprayitno.hita@gmail.com

\begin{abstract}
ABSTRAK
Jalan tol Bali Mandara adalah jalan tol pertama di pulau Bali yang dibangun dengan tujuan untuk mengurai kemacetan jalan bypass I Gusti Ngurah Rai yang mulai jenuh pada saat jam sibuk atau liburan panjang. Jalan tol Bali Mandara mulai dibangun pada awal tahun 2012 dan telah berhasil memenuhi tujuan awal pembangunannya, yaitu sebagai pengurai kemacetan dan alternatif jalan yang mengalirkan arus lalu lintas melalui 3 gerbang yaitu, gerbang Nusa Dua, gerbang Ngurah Rai dan gerbang Benoa. Namun demikian, berdasarkan data lalu lintas harian rata-rata per tahun, jalan tol ini mengalami penurunan dari sisi pertumbuhan mulai dari bulan Agustus tahun 2017 yang juga berpengaruh terhadap pendapatan dari PT Jasa Marga Bali Tol. Oleh karena itu, tujuan dari studi ini adalah mengidentifikasi kebutuhan pengembangan dengan kesesuaian strategi yang dijalankan pada saat ini. Dengan adanya strategi yang tepat, diharapkan pengembangan yang dilakukan oleh anak perusahaan PT Jasa Marga (Persero) ini dapat meningkatan pendapatan baik dari bisnis utama berupa pendapatan tol maupun dari unit usaha lain (non tol) serta meningkatkan nilai perusahaan melalui pendekatan manajemen aset infrastruktur. Metoda penelitian meliputi studi literatur, Focus Group Discussion (FGD) dan Analisa SWOT. Berdasarkan hasil analisis, didapatkan peringkat dalam penentuan strategi diantaranya peringkat 1 yaitu meningkatkan pendapatan melalui bisnis non jalan tol, peringkat 2 yaitu melakukan alternatif pendanaan ulang dan peringkat 3 yaitu meningkatkan pendapatan bisnis jalan tol.
\end{abstract}

Kata Kunci : Jalan Tol Bali Mandara, manajemen aset infrastruktur, strategi pengembangan usaha, manajemen strategi.

\section{PENDAHULUAN}

Jalan tol Bali Mandara adalah jalan tol yang dibangun dengan tujuan mengurai kemacetan di jalan bypass I Gusti Ngurah Rai. Di sisi lain, pembangunan jalan baru di atas tanah di wilayah Denpasar Selatan sulit untuk dilaksanakan mengingat keterbatasan lahan, harga tanah yang sangat mahal dan benturan dengan pelestarian budaya, adat-istiadat, serta agama. Sebelum adanya jalan tol Bali Mandara, satu-satunya akses yang menghubungkan wilayah Bali utara dan Bali selatan hanyalah jalan bypass I Gusti Ngurah Rai. Jika akses ini terganggu atau mengalami kemacetan terutama pada saat akhir pekan maupun pada saat musim liburan, maka hubungan utara-selatan Bali terputus. Pada tahun 2010, bypass I Gusti 
Ngurah Rai kondisinya sudah sangat macet, terutama di persimpangan Dewa Ruci dan persimpangan sebidang (pertigaan) ke arah Bandara Ngurah Rai. Untuk menempuh jarak 10 kilometer saja diperlukan waktu tidak kurang dari 2 (dua) jam. Kemacetan di Bali telah menyebabkan ekonomi biaya tinggi terutama konsumsi bahan bakar, oli, pemakaian suku cadang dan yang paling berharga adalah waktu tempuh perjalanan mengingat tujuan wisatawan ke Bali adalah untuk mengunjungi sebanyak mungkin lokasi-lokasi wisata. Kondisi kemacetan di Bali tidak hanya dikeluhkan oleh wisatawan, namun pengusaha hotel, penyedia jasa transportasi, sampai sopir taksi.

Hingga saat ini jalan tol Bali Mandara sudah beroperasi selama kurang lebih 6 tahun. Sejauh ini, mulai terdapat beberapa kendala yang dihadapi oleh PT Jasa Marga Bali Tol selaku Badan Usaha Jalan Tol (BUJT) yang mengelola. Penyebab utama permasalahan yang dihadapi perusahaan adalah terjadi tren menurun dari pertumbuhan jumlah kendaraan yang menggunakan atau melewati jalan tol Bali Mandara. Penurunan ini disebabkan oleh animo masyarakat maupun wisatawan yang semakin berkurang untuk menggunakan jalan tol Bali Mandara yang dipengaruhi oleh membaiknya kinerja lalu lintas jalan bypass I Gusti Ngurah Rai. Membaiknya kinerja lalu lintas ini didukung oleh pembangunan jalan underpass Dewa Ruci yang sebelumnya turut menjadi penyebab kemacetan. Dengan demikian masyarakat dan wisatawan cenderung memilih untuk melewati jalan bypass Ngurah Rai apabila kondisi lalu lintas normal. Jalan tol Bali Mandara kembali menjadi pilihan hanya ketika jalan bypass I Gusti Ngurah Rai mulai macet dan kondisi itu pun relatif jarang terjadi. Berdasarkan permasalahan tersebut, maka tantangan yang dihadapi oleh PT Jasa Marga Bali Tol secara umum adalah adalah sebagai berikut :

- Penurunan pertumbuhan volume kendaraan pada jalan tol Bali Mandara yang berpengaruh terhadap pendapatan

- Selanjutnya, penurunan pendapatan berpengaruh terhadap kemampuan pemenuhan kewajiban perusahaan untuk mengembalikan pokok pinjaman (hutang) dan bunga bank dari kredit sindikasi

- Perubahan operasi dari human base menjadi electronic base melalui penerapan Gardu Tol Otomatis (GTO) menggunakan uang elektronik di seluruh gerbang tol

Dalam menghadapi beberapa tantangan tersebut, maka diperlukan strategi yang tepat untuk tetap bisa menjalankan perusahaan dengan baik. Oleh karena itu, studi ini berusaha untuk mengevaluasi strategi yang sudah dijalankan dengan kebutuhan pengembangan usaha yang ada. Dengan demikian, diharapkan hasil analisis dapat bermanfaat sebagai alternatif solusi bagi perusahaan. Adapun studi ini terbatas pada analisis tantangan finansial perusahaan dan tidak membahas mengenai tantangan terkait perubahan operasi dari human base menjadi electronic base yang berpengaruh terhadap penataan ulang sumber daya manusia (SDM) dan struktur organisasi.

\section{STUDI PUSTAKA}

\section{Manajemen Aset Infrastruktur}

Manajemen Aset Infrastruktur \& Fasilitas adalah suatu program atau pengetahuan untuk mengelola, suatu infrastruktur agar tetap bisa menjalankan fungsinya dengan baik secara terus-menerus sepanjang masih dibutuhkan, secara ekonomis, efisien, dan efektif dan memenuhi prinsip green atau sustainability dalam hubungannya dengan aspek lingkungan, aspek sosial, dan aspek ekonomi (Suprayitno \& Soemitro 2018).

\section{Manajemen Strategik}

Arti manajemen strategik adalah seni dan pengetahuan dalam merumuskan, menerapkan, dan mengevaluasi keputusan lintas fungsional yang memungkinkan organisasi untuk mencapai tujuannya. Manajemen strategik berfokus pada upaya untuk 
mengintegrasikan manajemen, pemasaran, keuangan, operasi, penelitian dan pengembangan, dan sistem informasi komputer untuk mencapai keberhasilan organisasi (David, 2008).

Manajemen strategik adalah sekelompok keputusan dan tindakan manajerial yang menentukan kinerja jangka panjang organisasi. Jadi dapat disimpulkan bahwa makna manajemen strategik adalah proses atau taktik bagaimana perusahaan dapat menyelesaikan tujuannya dengan mensinergikan fungsi-fungsi organisasi di dalamnya (Robbins, 2007).

\section{Strategi Manajemen Aset}

Strategi manajemen aset adalah proses berkelanjutan untuk menentukan kisaran dan tingkat aset yang diperlukan untuk mencapai tujuan strategis (Clarence Valley Council, 2007). Kerangka kerja strategi manajemen aset bertujuan untuk memastikan pengambilan keputusan oleh manajer yang berinvestasi dan mengelola aset untuk mencapai tujuan pemberian layanan suatu institusi. Pada prinsipnya, strategi manajemen aset adalah mempertahankan fungsi aset sesuai dengan rencana dan memenuhi kesenjangan antara kebutuhan aset masa depan dan kondisi aset saat ini. Hasil analisis dalam bentuk strategi manajemen aset infrastruktur yang meliputi pemeliharaan aset yang ada, rehabilitasi aset yang membutuhkan perbaikan, pembangunan aset baru, solusi untuk pemanfaatan kelebihan aset dan solusi non-aset (Anwar \& Supriyatna, 2003).

\section{Gambaran Umum Jalan Tol Bali Mandara}

Salah satu aset infrastruktur adalah jalan yang merupakan prasarana transportasi. Pada pembahasan selanjutnya, lebih difokuskan pada jalan tol yang merupakan jalan umum sebagai bagian dari sistem jaringan jalan dan sebagai jalan nasional yang penggunanya diwajibkan membayar tol. Tol adalah sejumlah uang tertentu yang dibayarkan untuk penggunaan jalan tol (Keputusan Menteri Kimpraswil Nomor 354/KPTS/M/2001). Jalan tol termasuk dalam aset infrastruktur yang harus dikelola dengan baik pada seluruh siklus hidupnya sesuai dengan prinsip manajemen aset infrastruktur. Adapun profil umum jalan tol Bali Mandara adalah sebagai berikut.

Tabel 1. Profil Jalan Tol Bali Mandara

\begin{tabular}{lll}
\hline Profil & Jumlah & Keterangan \\
\hline Panjang Jalan & $12,7 \mathrm{~km}$ & \\
Simpang susun & 2 buah & Benoa dan Ngurah Rai \\
Jembatan laluan nelayan & 2 buah & - \\
Gerbang tol & 3 buah & Nusa Dua, Ngurah Rai, Benoa \\
Gardu Tol & 20 buah & Seluruhnya GTO \\
Biaya investasi & 2,4 Triliun & \\
Masa Konsensi & 2057 & \\
Sistem Operasi & - & Terbuka \\
\hline Sumber : Annual Report JBT, 2018 & &
\end{tabular}

Berdasarkan tabel di atas, jalan tol Bali Mandara dioperasikan dengan sistem terbuka, yaitu pengguna jalan tol bisa masuk dari Gerbang Tol manapun, kemudian membayar tol di gardu tol, dan bebas keluar ke tempat tujuan yang diinginkan.

\section{Pembangunan Jalan Tol Bali Mandara}

Sebelumnya terdapat rencana pembangunan jembatan tol Serangan - Tanjung Benoa yang menjadi salah satu solusi dan sudah masuk dalam rencana jaringan jalan tol nasional di pulau Bali, namun rencana ini menghadapi hambatan teknis dan hambatan finansial. Menghadapi hambatan tersebut, maka dirumuskan rencana pengganti mengingat diperlukan jalan alternatif dan peningkatan fasilitas transportasi berupa prasarana jalan yang harus selesai dalam waktu maksimal 2 tahun karena pada akhir tahun 2013 terdapat acara penting tingkat internasional yang akan diselenggarakan di Bali (Karim, 2018). Dengan demikian 
pembangunan ruas jalan tol Nusa Dua - Ngurah Rai - Benoa merupakan salah satu program prioritas Pemerintah yang termasuk dalam 6 koridor ekonomi (Sumatera, Jawa, Kalimantan, Bali-Nusa Tenggara dan Papua Maluku) yang merupakan bagian dari Master Plan Percepatan dan Perluasan Pembangunan Ekonomi Indonesia (MP3EI) 20011-2025 (BAPPENAS, 2011), dengan tujuan: mengatasi permasalahan kemacetan di wilayah Bali bagian selatan, sebagai pengembangan ekonomi di Pulau Bali dan mendukung pelaksanaan APEC pada bulan Oktober tahun 2013. Selanjutnya, Perjanjian Pengusahaan Jalan Tol (PPJT) ditandatangai pada tanggal 16 Desember 2011 dan pelaksanan pembangunan harus selesai dalam waktu 16 bulan. Pada tanggal 23 September 2013 jalan tol Bali Mandara diresmikan oleh Presiden RI. Perkembangan jalan tol Bali-Mandara secara garis besar dapat dilihat pada Gambar 1 di bawah ini.

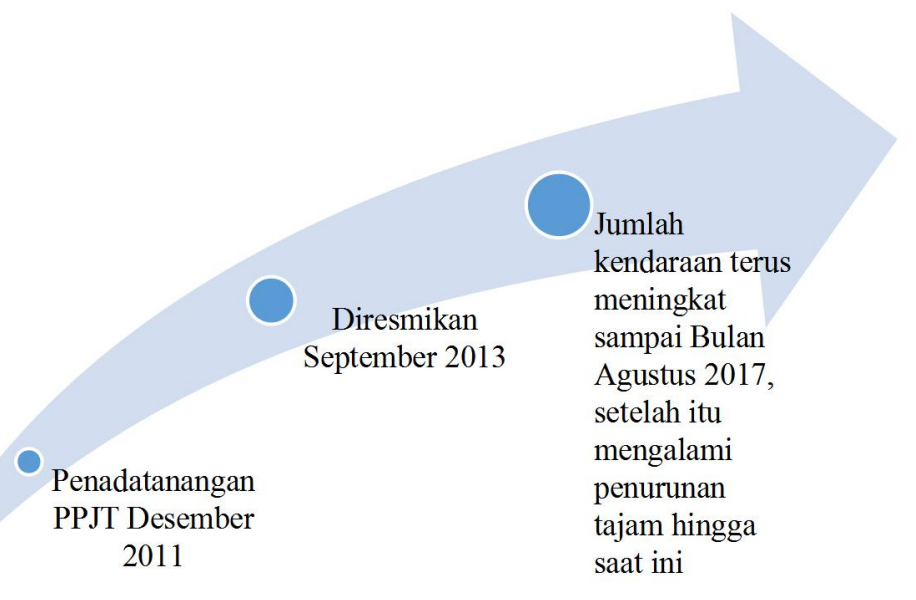

Gambar 1. Perkembangan Jalan Tol Bali Mandara

Pemerintah kemudian memerintahkan empat BUMN, PT Jasa Marga (Persero) Tbk., PT Pelindo III (Persero), PT Angkasa Pura I (Persero), dan PT Pengembangan Pariwisata Bali (Persero) yang sekarang berubah nama menjadi PT Pengembangan Pariwisata Indonesia (Persero) atau ITDC untuk mencari solusi paling efektif mengatasi kemacetan di Bali selatan dengan menggunakan konsep jalan tol. Keempat BUMN tersebut kemudian sepakat membentuk lembaga dalam pembiayaan bersama suatu proyek atau perusahaan yang dilakukan oleh dua atau lebih bank atau lembaga keuangan yang selanjutnya disebut konsorsium dan menunjuk Jasa Marga sebagai pemimpin konsorsium tersebut, dengan pertimbangan Jasa Marga merupakan satu-satunya BUMN yang paling berpengalaman di bidang pengelolaan jalan tol. Keempat Konsorsium BUMN sepakat membentuk badan usaha jalan tol (BUJT) dengan nama PT Jasamarga Bali Tol, dan telah memperoleh pengesahan dari Menteri Hukum dan HAM melalui Surat Keputusan Nomor AHU-57740.AH.01.01, tanggal 25 November 2011. Pada tanggal 16 Desember 2011, disaksikan oleh Menteri Pekerjaan Umum dan Perumahan Rakyat, PT Jasamarga Bali Tol selaku Badan Usaha Jalan Tol (BUJT) dan Badan Pengatur Jalan Tol (BPJT) atas nama Pemerintah c.q. Kementerian Pekerjaan Umum menandatangani Perjanjian Pengusahaan Jalan Tol yang disingkat menjadi PPJT (JBT, 2018).

Adapun ketentuan terkait Jalan Tol diatur melalui antara lain peraturan-peraturan sebagai berikut.

- Peraturan Pemerintah Nomor 30/2017: Perubahan Ketiga Atas PP 15/2005 Tentang Jalan Tol

- Keputusan Menteri Permukiman dan Prasarana Wilayah Nomor 353/KPTS/M/2001 Tentang Ketentuan Teknik, Tata Cara Pembangunan dan Pemeliharaan Jalan Tol 
- Keputusan Menteri Permukiman dan Prasarana Wilayah Nomor 354/KPTS/M/2001 Tentang Kegiatan Operasi Jalan Tol

- Peraturan Menteri Pekerjaan Umum dan Perumahan Rakyat Nomor 01/PRT/M/2017 Tentang Tata Cara Pelaksanaan Pengadaan Badan Usaha Untuk Pengusahaan Jalan Tol

- Peraturan Menteri Pekerjaan Umum dan Perumahan Rakyat Nomor 06/PRT/M/2018 Tentang Wewenang dan Tugas Direktorat Jenderal Bina Marga, Badan Pengatur Jalan Tol dan Badan Usaha Jalan Tol Dalam Penyelenggaraan Jalan Tol

\section{Aspek Pendanaan Jalan Tol Bali Mandara}

Pembangunan jalan tol Bali Mandara dibiayai melalui kredit sindikasi oleh 5 Bank yaitu Perjanjian Kredit Sindikasi antara PT Jasamarga Bali Tol sebagai BUJT dengan perusahaan perbankan yang terdiri dari :

1. PT Bank Mandiri (Persero) Tbk.

2. PT Bank Negara Indonesia (Persero) Tbk.

3. PT Bank Rakyat Indonesia (Persero) Tbk.

4. PT Bank Central Asia Tbk.

5. PT Bank Tabungan Negara (Persero) Tbk.

6. PT Bank Pembangunan Daerah Bali

Kredit sindikasi merupakan suatu pinjaman yang diberikan oleh beberapa kreditur sindikasi, yang biasanya terdiri dari bank - bank dan atau lembaga - lembaga keuangan lainnya kepada seorang debitur, yang biasanya berbentuk badan hukum untuk membiayai satu atau beberapa proyek milik debitur. Pinjaman tersebut diberikan secara sindikasi mengingat jumlah yang dibutuhkan untuk membiayai proyek tersebut sangat besar, sehingga tidak mungkin dibiayai oleh kreditur tunggal (Sutedi, 2012).

\section{Aspek Kelembagaan}

Untuk mendukung gerak pertumbuhan ekonomi, Indonesia membutuhkan jaringan jalan yang handal. Melalui Peraturan Pemerintah No. 04 Tahun 1978, pada tanggal 01 Maret 1978 Pemerintah mendirikan PT Jasa Marga (Persero) Tbk. yang merupakan Badan Usaha Milik Negara (BUMN), yaitu suatu badan usaha dimana modalnya dimiliki oleh pemerintah yang berasal dari kekayaan negara. BUMN termasuk pelaku ekonomi dalam sistem perekonomian nasional. BUMN didirikan dengan tujuan untuk mewujudkan kesejahteraan masyarakat dan memenuhi kebutuhan masyarakat di berbagai sektor. Tugas utama Jasa Marga adalah merencanakan, membangun, mengoperasikan dan memelihara jalan tol serta sarana kelengkapannya agar jalan tol dapat berfungsi sebagai jalan bebas hambatan yang memberikan manfaat lebih tinggi daripada jalan umum bukan tol. PT Jasa Marga Bali Tol merupakan anak perusahaan PT Jasa Marga (Persero) dengan kegiatan usaha utama melakukan perencanaan teknis, pelaksanaan konstruksi, pengoperasian dan pemeliharaan ruas jalan tol Bali Mandara dan kegiatan usaha penunjang yaitu mengusahakan lahan di ruang milik jalan, tempat istirahat dan pelayanan fasilitas-fasilitas jalan tol untuk meningkatkan pendapatan usaha. Berikut, pada Tabel 2, disampaikan komposisi pemegang saham dari jalan tol Bali Mandara.

Tabel 2. Pemegang Saham Tol Bali Mandara

\begin{tabular}{ll}
\hline \multicolumn{1}{c}{ Pemegang Saham } & Persentase \\
\hline PT Jasa Marga (Persero), Tbk & $55,00 \%$ \\
PT Pelabuhan Indonesia III (Persero) & $17,58 \%$ \\
Pemerintah Provinsi Bali & $8,01 \%$ \\
Pemerintah Kabupaten Badung & $8,01 \%$ \\
PT Angkasa Pura I (Persero) & $8,00 \%$
\end{tabular}




\begin{tabular}{ll}
\hline \multicolumn{1}{c}{ Pemegang Saham } & Persentase \\
\hline PT Adhi Karya (Persero), Tbk & $1,00 \%$ \\
PT Hutama Karya (Persero) & $1,00 \%$ \\
PT Pengembangan Pariwisata Indonesia & $1,00 \%$ \\
PT Wijaya Karya (Persero) & $0,40 \%$ \\
\hline Sumber: Laporan Tahunan JBT, 2018 &
\end{tabular}

PT Jasa Marga Bali Tol merupakan Badan Usaha Jalan Tol yang selanjutnya disingkat BUJT adalah badan usaha berbentuk perseroan terbatas yang khusus didirikan oleh Badan Usaha pemenang Pengadaan Badan Usaha Untuk Pengusahaan Jalan Tol untuk melaksanakan Pengusahaan Jalan Tol dengan menandatangani dan melaksanakan PPJT. PT Jasa Marga Bali Tol termasuk Public Sector Organization, dengan jenis Quasi Profit Organization yaitu setengah mencari laba dan membantu pemerintah menyediakan barang untuk publik.

\section{Strategi Umum Kegiatan PT Jasa Marga Bali Tol}

Dalam menjalankan kegiatan sesuai dengan tugas dan fungsinya, strategi umum PT Jasa Marga Bali Tol adalah sebagai berikut :

- Mengoperasikan jalan tol dengan standar pelayanan prima untuk mencapai kepuasan pelanggan/pengguna jalan tol

- Mengelola dan memelihara aset jalan tol secara efektif dan efisien

- Mencari terobosan dan peluang usaha yang sejalan dengan bisnis inti untuk meningkatkan pendapatan usaha lain

- Mengelola keuangan secara efisien sehingga mampu menyeimbangkan antara pendapatan dan kewajiban pembayaran utang, serta kebutuhan biaya pengoperasian dan pemeliharaan

\section{Pengembangan Bisnis Jalan Tol}

$\underline{\text { Usaha Jalan Tol }}$

Bidang usah a Jasa Marga adalah membangun dan menyediakan jasa pelayanan jalan tol. Dikutip dari Jasa Marga (2019), PT Jasa Marga (Persero) melakukan aktifitas usaha sebagai berikut :

1. Melakukan investasi dengan membangun jalan tol baru.

2. Mengoperasikan dan memelihara jalan tol.

3. Mengembangkan usaha lain, seperti tempat istirahat, iklan, jaringan serat optik dan lainlain, untuk meningkatkan pelayanan kepada pemakai jalan dan meningkatkan hasil usaha perusahaan.

4. Mengembangkan usaha lain dalam koridor jalan tol.

\section{$\underline{\text { Usaha Non Jalan Tol }}$}

Dalam rangka mengoptimalkan aset, PT Jasa Marga Bali Tol melakukan pengembangan usaha non tol yang mendukung pengembangan dan pengoperasian jalan tol melalui pengembangan bisnis pada koridor jalan tol atau pengembangan bisnis yang memanfaatkan kompetensi Perseroan. Pengembangan usaha non tol ini dilakukan dengan mengkapitalisasi aset-aset berwujud dan aset-aset tidak berwujud milik Perseroan untuk meningkatkan nilai tambah bagi para pemangku kepentingan, seperti pengembangan properti pada koridor jalan tol atau pemanfaatan daerah ruang milik jalan tol untuk pemasangan jaringan fiber optik. Pengembangan bisnis dapat dilaksanakan secara mandiri maupun dikerjasamakan dengan mitra strategis. Adapun bidang pengembangan usaha non tol yang telah dilaksanakan oleh Perseroan adalah sebagai berikut :

1. Pengembangan properti pada koridor jalan tol, antara lain pengembangan area Properti dan Tempat Istirahat serta Pelayanan (TIP) yang masih dalam tahap perencanaan. 
2. Pengembangan jasa yang memanfaatkan aset perseroan, antara lain penyewaan lahan untuk iklan dan utilitas serta jasa pengoperasian dan pemeliharaan jalan tol yang sudah dilaksanakan.

\section{PENGUMPULAN DATA}

Pengumpulan data dalam studi ini dilakukan melalui 2 tahapan. Tahap pertama dilakukan dengan menggunakan Focus Group Discussion (FGD) dengan pihak pengelola jalan tol Bali Mandara yaitu PT Jasa Marga Bali Tol. Berdasarkan FGD yang telah dilakukan, dapat diketahui beberapa tantangan yang harus dihadapi oleh perusahaan beserta strategi yang telah dijalankan pada saat ini serta rencana strategi yang akan dijalankan. Setelah mendapatkan data primer melalui FGD, maka pada tahap kedua dilakukan studi literatur sebagai dasar analisis berdasarkan dua sudut pandang, yaitu sudut pandang akademis maupun sudut pandang praktis dengan mencari bahan-bahan pustaka yang mendukung baik berupa artikel dalam jurnal, hasil simposium, buku pendukung, maupun sumber pustaka lain yang relevan. Kemudian dilakukan analisis secara deskriptif untuk menghasilkan alternatif penyelesaian permasalahan yang dihadapi oleh perusahaan pada saat ini dengan menilai kesesuaian strategi yang sudah dijalankan, maupun rencana strategi yang akan dijalankan.

\section{ANALISIS PENELITIAN}

\section{Pertumbuhan Lalu Lintas Harian Rata Rata dan Pendapatan PT Jasa Marga Bali Tol}

Sejak diresmikan pada bulan September 2013, Jalan Tol Bali Mandara terus mengalami peningkatan maupun pertumbuhan volume kendaraan, namun demikian jika ditinjau per bulan, peningkatan pertumbuhan tersebut mencapai puncaknya pada bulan Juli 2017, dan mulai bulan Agustus 2017 terus mengalami penurunan pertumbuhan hingga saat ini. Berdasarkan Laporan Tahunan PT Jasa Marga Bali Tol tahun 2018, ikhtisar operasional jalan tol Bali Mandara dapat dilihat pada Tabel 3 sebagai berikut.

Tabel 3. Ikhtisar Operasional

\begin{tabular}{|l|l|l|l|l|l|}
\hline \multicolumn{1}{|c|}{ Uraian/Tahun } & \multicolumn{1}{|c|}{$\mathbf{2 0 1 4}$} & \multicolumn{1}{|c|}{$\mathbf{2 0 1 5}$} & \multicolumn{1}{|c|}{$\mathbf{2 0 1 6}$} & \multicolumn{1}{|c|}{$\mathbf{2 0 1 7}$} & \multicolumn{1}{|c|}{$\mathbf{2 0 1 8}$} \\
\hline Volume Lalu Lintas Transaksi (juta kend.) & 14,31 & 16,50 & 17,46 & 18,20 & 18,26 \\
\hline Pertumbuhan & - & 2,19 & 0,96 & 0,74 & 0,06 \\
\hline Volume Transaksi LHR (ribu kendaraan) & 39,421 & 45,457 & 47,973 & 50,135 & 50,294 \\
\hline Pertumbuhan & - & 6053 & 2516 & 2162 & 159 \\
\hline Pendapatan Tol Harian Rata-rata (juta Rp) & 292,40 & 338,05 & 393,55 & 412,93 & 444,69 \\
\hline Pertumbuhan & - & 46,65 & 55,5 & 19,38 & 31,76 \\
\hline
\end{tabular}

Sumber : Annual Report JBT, 2018

Berdasarkan Tabel 3 di atas, dapat diketahui bahwa volume lalu lintas transaksi mengalami peningkatan pada setiap tahun, dari tahun 2014 sampai tahun 2018. Namun demikian, jika diperhatikan nilai pertumbuhannya semakin menurun dibandingkan dengan tahun sebelumnya. Sebagai contoh pertumbuhan volume lalu lintas transaksi turun drastis dari 2,19 juta kendaraan pada tahun 2015 menjadi 0,96 juta kendaraan pada tahun 2016. Kemudian untuk pertumbuhan volume transaksi LHR juga turun drastis sebesar 2516 juta kendaraan pada tahun 2016 dan menjadi 159 juta kendaraan pada tahun 2018 dibandingkan tahun sebelumnya. Untuk grafik penurunan volume kendaraan khusus pada tahun 2017 ditampilkan per triwulan dapat dilihat pada Gambar 2 di bawah ini. 


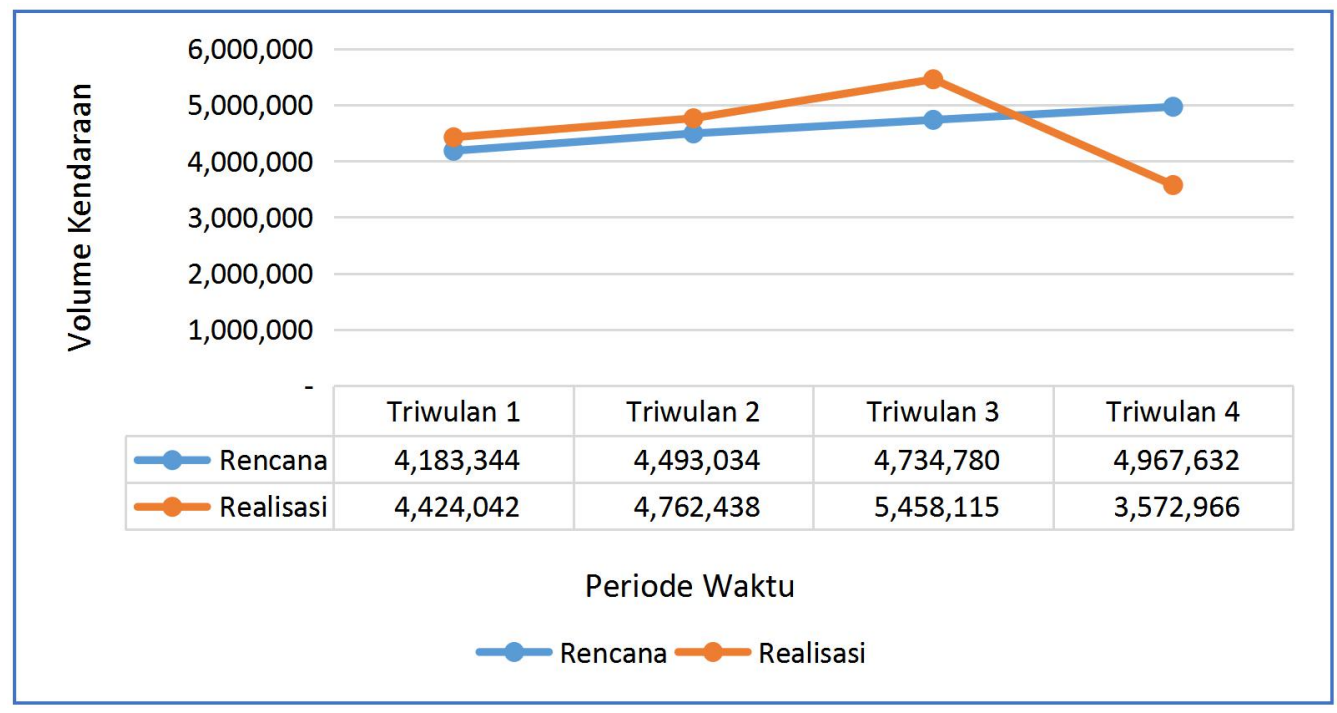

Gambar 2. Rencana dan Realisasi Pertumbuhan Arus Lalu Lintas Tahun 2017

Berdasarkan gambar diatas, dapat dijelaskan bahwa volume kendaraan masih tinggi pada triwulan 1 , triwulan 2 , dan triwulan 3 , bahkan berada di atas rencana yang ditetapkan Namun demikian pada triwulan 4, volume kendaraan menurun drastis sehingga terdapat deviasi yang cukup signifikan antara rencana dan realisasinya sebesar $28,08 \%$. Selanjutanya turunnya volume kendaraan berpengaruh terhadap pendapatan tol sebagaimana terlihat pada Gambar 3 di bawah ini.

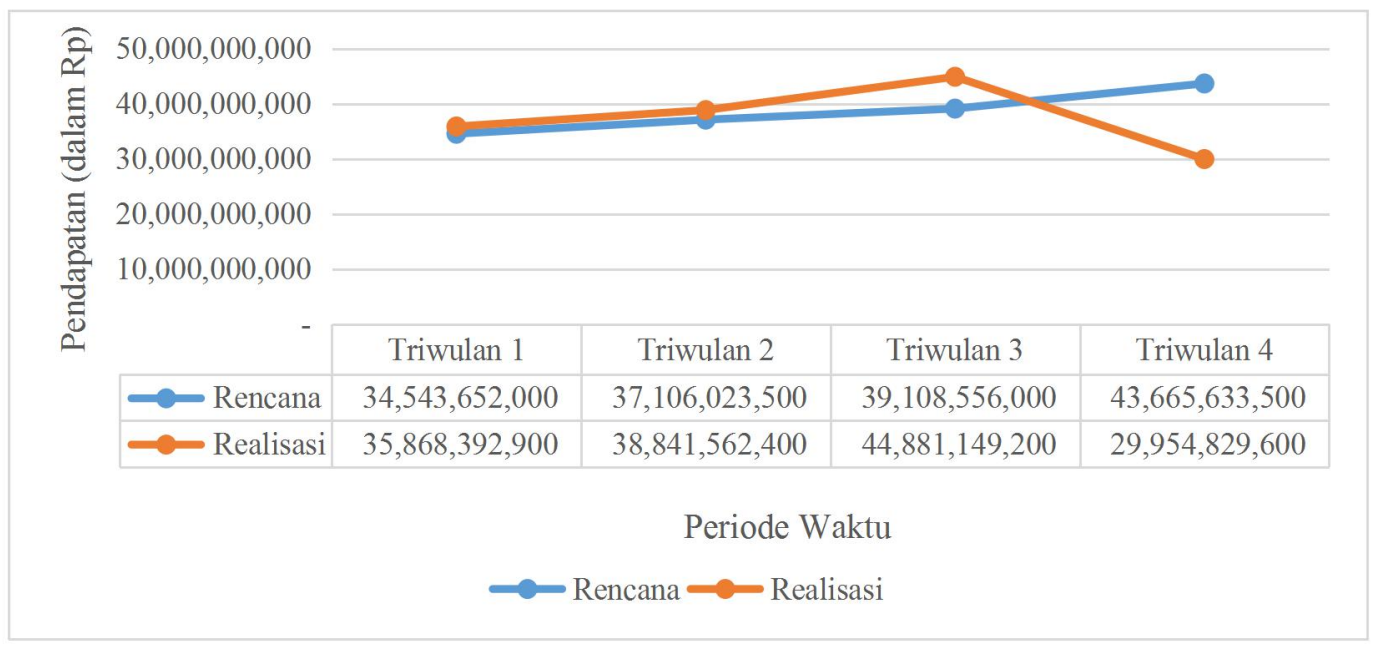

Gambar 3. Rencana dan Realisasi Pendapatan Tol Tahun 2017

Pada Gambar 3 dapat dilihat bahwa bentuk grafik hampir sama pada Gambar 1, maka dikarenakan pertumbuhan volume lalu lintas yang menurun, akan berpengaruh terhadap penurunan pendapatan tol di triwulan 4 dengan deviasi sebesar Rp 13.710.803.900,- antara rencana dan realisaisnya. Berdasarkan Laporan Tahunan PT Jasa Marga Bali Tol tahun 2018, turunnya pendapatan dari tarif tol juga membuat perusahaan manggung kerugian pada tahun 2016, tahun 2017 dan tahun 2018 sebagaimana terlihat pada Tabel 4 di bawah ini. 
Tabel 4. Laporan Laba Rugi Komprehensif (dalam rupiah)

\begin{tabular}{llll}
\hline \multicolumn{1}{c}{ Uraian } & \multicolumn{1}{c}{$\mathbf{2 0 1 6}$} & \multicolumn{1}{c}{$\mathbf{2 0 1 7}$} & \multicolumn{1}{c}{$\mathbf{2 0 1 8}$} \\
\hline Pendapatan Usaha & 147.109 .042 .324 & 152.960 .097 .230 & 163.632 .350 .433 \\
Beban Usaha dan Operasi & 46.704 .488 .198 & 49.760 .418 .118 & 51.477 .850 .824 \\
EBITDA & 98.321 .854 .656 & 102.620 .305 .629 & 112.154 .499 .609 \\
Jumlah Pendapatan/Beban Lain-lain & $(126.771 .768 .427)$ & $(119.462 .543 .864)$ & $(115.952 .496 .716)$ \\
\hline Rugi Sebelum Pajak & $\mathbf{( 5 6 . 8 0 2 . 8 2 2 . 3 1 7 )}$ & $\mathbf{( 4 6 . 1 4 1 . 6 7 2 . 4 8 0 )}$ & $\mathbf{( 2 9 . 2 7 5 . 5 7 9 . 2 3 0 )}$ \\
Rugi Bersih & $\mathbf{( 7 6 . 1 4 3 . 0 3 7 . 9 7 8 )}$ & $\mathbf{( 6 5 . 8 9 2 . 7 5 4 . 8 7 9 )}$ & $\mathbf{( 4 8 . 0 2 8 . 3 7 9 . 1 7 0 )}$ \\
\hline
\end{tabular}

Sumber : Annual Report JBT, 2018

Berdasarkan Tabel 4 di atas dapat diketahui sejak tahun 2016, PT Jasa Marga Bali Tol sudah mengalami kerugian dari kegiatan operasionalnya. Sebagai anak perusahaan PT Jasa Marga (Persero) yang merupakan BUMN, PT Jasa Marga Bali Tol dituntut untuk bisa meningkatkan kinerja keuangannya untuk menghasilkan keuntungan. Selain mengalami kerugian, perusahaan juga masih harus membayar pokok kredit investasi kepada bank sindikasi yang membiayai proyek pembangunan jalan tol Bali-Mandara tersebut. Perlu diketahui bahwa EBITDA adalah besaran keuntungan yang didapatkan sebelum bunga, pajak, depresiasi dan amortisasi. Rugi bersih perusahaan berdasarkan data terakhir pada tahun 2018 yaitu sebesar $\mathrm{Rp}$ 48,03 milyar. Walaupun kerugian perusahaan mengalami tren menurun, namun besar kerugian masih tergolong cukup tinggi, sehingga diperlukan strategi yang tepat untuk terus mengurangi nilai kerugian perusahaan.

\section{Strategi yang Telah Dijalankan}

Menghadapi permasalahan tersebut, maka dapat dikelompokkan 3 strategi utama yang telah direncanakan maupun yang telah dilakukan oleh PT Jasa Marga Bali Tol yaitu sebagai berikut.

1. Meningkatkan Pendapatan Bisnis Jalan Tol

Bisnis utama dari perusahaan pengelola jalan tol adalah pengumpulan tarif tol dari pengguna jalan tol. Pada saat ini seluruh transaksi di jalan tol Bali-Mandara telah menggunakan sistem gardu tol otomatis (GTO), di mana dalam transaksi pembayarannya menggunakan uang elektronik atau transaksi non tunai. Menurunnya jumlah kendaraan yang melewati jalan tol Bali-Mandara merupakan suatu tantangan bagi perusahaan, oleh karena itu saat ini perusahaan menetapkan strategi sebagai berikut :

a. Tempat Pelayanan dan Wisata (TPW)

Strategi ini merupakan suatu langkah yang telah digagas oleh perusahaan yang sampai dengan saat ini telah sampai pada tahap perencanaan. Strategi ini dapat mempengaruhi pendapatan melalui dua cara, pertama meningkatkan minat pengguna jalan untuk melewati jalan tol dengan membayar tarif tol melalui daya tarik TPW dan kedua adalah pengguna jalan yang berhenti di TPW dapat menyumbang pendapatan dari transaksi yang dilakukan di TPW. Secara umum konsep TPW menggunakan pendekatan untuk mengenalkan budaya asli Bali melalui mitologi kepada wisatawan dengan sentuhan teknologi yang dinamakan Bedawang Nala.

b. Penambahan Panjang Jalan Tol

Strategi penambahan panjang ruas jalan tol masih merupakan strategi yang berada pada tahap inisiasi, namun belum dilakukan perencanaan secara umum maupun secara detail. Penambahan panjang jalan tol dari kondisi eksisting diharapkan dapat meningkatkan volume kendaraan yang melintas pada jalan tol karena dengan penambahan panjang ruas jalan tol akan menambah simpul-simpul atau pusat-pusat kegiatan yang terhubung. Hal ini akan meningkatkan volume kendaraan melalui transaksi pada gerbang tol baru yang akan dibangun. 
2. Meningkatkan Pendapatan Melalui Bisnis Non Jalan Tol

Dalam upaya untuk mengembangkan aset perusahaan, maka PT Jasa Marga Bali Tol telah berupaya untuk melaksanakan pengembangan bisnis non jalan tol melalui kegiatan sebagai berikut.

a. Pembangkit Listrik Tenaga Surya

Perencanaan mengenai pemasangan pembangkit listrik tenaga surya telah direncanakan oleh perusahaan untuk memaksimalkan pemanfaatan aset yang ada. Pembangkit listrik tenaga surya ini berfungsi ganda yaitu sebagai peneduh di lajur motor dan sebagai pemasok listrik. Listrik yang dihasilkan nantinya dapat digunakan untuk kebutuhan operasional jalan tol atau dijual kepada PLN. Dengan demikian, manfaat serta nilai aset infrastruktur jalan tol dapat dimaksimalkan.

b. Pemasangan Reklame

Pemasangan reklame di sepanjang koridor jalan tol merupakan suatu gagasan untuk memanfaatkan ruang sekaligus menambah pendapatan perusahaan melalui bisnis non jalan tol. Ide ini telah direalisasikan dengan pemasangan reklame pada beberapa titik. Namun demikian pemasangan reklame perlu dievaluasi kembali. Hendaknya pemasangan reklame dilakukan secara rapi, tertib dan tidak mengganggu keamanan serta keselamatan pengguna jalan serta harus menarik dan ditempatkan pada titik yang strategis, dengan demikian akan semakin banyak perusahaan yang berminat untuk memasang reklame dengan tarif yang kompetitif.

3. Melakukan Pendanaan Ulang

Pada tanggal 22 Juni 2012, Perusahaan menandatangani perjanjian kredit sindikasi No. 79 sebesar Rp1.739.300.000.000,- dengan PT Bank Mandiri (Persero) Tbk (Bank Mandiri),PT Bank Negara Indonesia (Persero) Tbk (BNI), PT Bank Rakyat Indonesia (Persero) Tbk (BRI), PT Bank Central Asia Tbk (BCA), PT Bank Tabungan Negara (Persero) Tbk (BTN) dan PT Bank Pembangunan Daerah Bali (BPD Bali) untuk pembiayaan pembangunan jalan tol Nusa Dua - Ngurah Rai - Benoa yang kemudian terakhir kali diubah dengan Akta Addendum III Perjanjian Kredit No. 3 tanggal 12 Januari 2017. Tujuan penggunaan kredit untuk membiayai pengadaan tanah dan konstruksi jalan tol serta membiayai $70 \%$ hutang pembayaran bunga dalam periode konstruksi.

Suku bunga tetap selama satu tahun sebesar $10 \%$ per tahun yang dihitung sejak tanggal penandatanganan Perjanjian Kredit. Setelah pengenaan suku bunga tetap selama satu tahun, Perusahaan wajib membayar bunga kepada para kreditur dengan suku bunga acuan ditambah margin 5\% per tahun. Maksimum kredit sebesar Rp1.622.000.000.000 termasuk bunga hutang yang harus dibayar selama masa konstruksi sebesar Rp117.300.000.000. Jangka waktu kredit berdasarkan perjanjian kredit ini adalah maksimum 15 tahun terhitung sejak tanggal perjanjian ini termasuk masa tenggang dengan jaminan berupa tagihan atas pendapatan tol dan pendapatan usaha lainnya dengan nilai penjaminan sebesar Rp2.484.780.000.000. Sampai dengan tanggal 31 Desember 2018, saldo utang bank Perusahaan adalah sebesar Rp1.201.374.175.912. Berdasarkan data tersebut, sisa hutang kredit sindikasi perusahaan dapat dilihat pada Gambar 4 di bawah ini. 


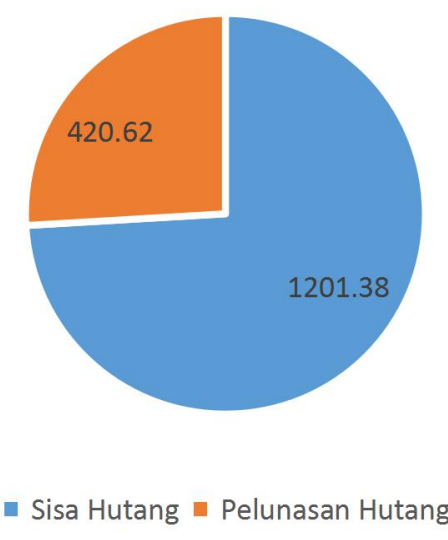

Gambar 4. Komposisi Hutang Perusahaan (dalam milyar rupiah)

Dengan adanya kerugian dari aktivitas operasional, beban pokok pinjaman, serta beban bunga pinjaman yang harus ditanggung, pendanaan ulang dengan menutupi pinjaman yang dimiliki dengan pinjaman lain menjadi sebuah alternatif pilihan. Pinjaman ulang ini dapat dilakukan dengan lembaga pemberi pinjaman yang saat ini sedang berjalan atau dengan lembaga pemberi pinjaman yang lain. Salah satu alternatif yang dapat dilakukan adalah merestrukturisasi hutang menjadi obligasi. Penerbitan obligasi memang menjadi pilihan pendanaan utama bagi emiten saat ini. Hal ini dikarenakan kupon obligasi masih lebih murah dibandingkan bunga pinjaman korporasi yang dipatok bank, apalagi bagi perusahaan yang punya rating utang bagus. Selain itu, perusahaan bisa melakukan pendanaan ulang melalui obligasi meski jatuh temponya masih lama.

Sementara bila mencari pinjaman bank, perusahaan harus terus membayar kupon dan pokok pinjaman. Dengan demikian, dari sisi biaya pendanaan, obligasi lebih murah (Kontan, 2018). Menerbitkan obligasi menjadi salah satu alternatif mencari sumber pembiayaan karena biaya pendanaan lebih rendah, dibandingkan pinjaman perbankan apabila suku bunga kredit sedang tinggi. Tingkat bunga yang tinggi bisa menambah beban keuangan perusahaan. Dengan demikian, terdapat kecenderungan perusahanan mengganti sumber pembiayaan karena beban bunga tinggi tersebut. Dikarenakan kelebihannya itu, banyak perusahaan yang cenderung memilih obligasi untuk mengganti sumber pendanaan. Selain itu dengan obligasi, biaya dapat ditekan dan disesuaikan dengan rencana pendanaan perusahan karena tidak terdapat bunga mengambang seperti hutang korporasi dari bank. Dengan demikian obligasi dapat mengunci strategi keuangan perusahaan, namun harus direncanakan dengan baik sejak awal, sehingga uang tersedia pada saat jatuh tempo. Sedangkan untuk kredit bank seperti yang tengah dilakukan perusahaan saat ini, kelebihannya fleksibilitas dan proses cepat tetapi kekurangannya adalah bunganya mengambang yang bisa menggerus keuangan perusahaan (Wareza, 2018).

\section{Penyusunan Strategi}

Setelah dilakukan analisis deskriptif, maka penentuan strategi pada studi ini dilanjutnkan dengan menggunakan analisis SWOT, analisis matriks Internal Factor Evaluation (IFE) dan matriks External Factor Evaluation (EFE) serta analisis Qualitative Strategic Planning Matrix (QSPM).

\section{Penyusunan Matriks SWOT}

SWOT adalah akronim dari kekuatan (Strenghts), kelemahan (Weakness), peluang (Opportunities), dan ancaman (Threats) dari lingkungan eksternal perusahaan. SWOT digunakan untuk menilai kekuatan-kekuatan dan kelemahan-kelemahan dari sumber-sumber 
daya yang dimiliki perusahaan dan kesempatan-kesempatan eksternal dan tantangantantangan yang dihadapi (Jogiyanto, 2005).

Semua organisasi memiliki kekuatan dan kelemahan dalam area fungsional bisnis. Tidak ada perusahaan yang sama kuatnya atau lemahnya dalam semua area bisnis. Kekuatan/kelemahan internal, digabungkan dengan peluang/ancaman dari eksternal dan pernyataan misi yang jelas, menjadi dasar untuk penetapan tujuan dan strategi. Tujuan dan strategi ditetapkan dengan maksud memanfaatkan kekuatan internal dan mengatasi kelemahan (David, 2008).

Penyusunan Komponen Matriks SWOT, baik untuk Kekauatan, Kelemahan, Peluang dan Ancaman, disampaikan pada Tabel 5 dibawah ini.

Tabel 5. Penyusunan Komponen Matriks SWOT

\begin{tabular}{|c|c|}
\hline \multicolumn{2}{|c|}{ Faktor Internal } \\
\hline Kekuatan & Kelemahan \\
\hline $\begin{array}{ll}\text { - } & \text { SDM yang kompetitif(S1) } \\
\text { - } & \text { Organisasi yang kondusif (S2) } \\
\text { - } & \text { Monitoring dan Evaluasi intern pekerjaan } \\
& (\mathrm{S} 3) \\
\text { - } & \text { Budaya Kerja (S4) }\end{array}$ & $\begin{array}{ll}\text { - } & \text { Sistem Manajemen yang terintegrasi (W1) } \\
\text { - } & \text { Sistem Keuangan Organisasi (W2) } \\
\text { - } & \text { Kerjasama dengan pihak bank dan } \\
& \text { pemerintah (W3) }\end{array}$ \\
\hline \multicolumn{2}{|c|}{ Faktor Eksternal } \\
\hline Peluang & Ancaman \\
\hline $\begin{array}{ll}\text { - } & \text { Stabilitas politik }(\mathrm{O} 1) \\
\text { - } & \text { Pertumbuhan penduduk }(\mathrm{O} 2) \\
\text { - } & \text { Kondisi Geografis }(\mathrm{O} 3)\end{array}$ & $\begin{array}{ll}\text { - } & \text { Adat istiadat masyarakat (T1) } \\
\text { - } & \text { Pengembalian Konsinyasi (T2) } \\
\text { - } & \text { Pendapatan Tol (T3) } \\
\text { - } & \text { Cuaca (T4) }\end{array}$ \\
\hline
\end{tabular}

Analisis Matriks IFE dan Matriks EFE

Dari hasil identifikasi indikator faktor internal dan eksternal pada tabel diatas, selanjutnya adalah memberkan bobot dan rating pada masing-masing indikator internal dan eksternal. Perhitungan Nilai Faktor dilakukan dengan menggunakan Matriks IFE dan Matriks EFE sebagai berikut.

a. Matriks IFE

Matriks IFE digunakan untuk mengetahui faktor-faktor internal perusahaan berkaitan dengan kekuatan dan kelemahan yang dianggap penting. Data dan informasi aspek internal perusahaan dapat digali dari beberapa fungsional perusahaan, misalnya dari aspek manajemen, keuangan, SDM, dan pemasaran. Adapun analisis menggunakan matriks IFE dapat dilihat pada Tabel 6 sebagai berikut.

Tabel 6. Analisis Matriks IFE

\begin{tabular}{|l|c|c|c|c|}
\hline \multicolumn{1}{|c|}{ Faktor Internal } & S/W & Bobot & Rating & Nilai \\
\hline SDM yang kompetitif & $\mathrm{S}$ & 0,16 & 3 & 0,48 \\
\hline Organisasi yang kondusif & $\mathrm{S}$ & 0,16 & 3 & 0,48 \\
\hline Monitoring dan evaluasi intern pekerjaan & $\mathrm{S}$ & 0,16 & 4 & 0,64 \\
\hline Budaya kerja & $\mathrm{S}$ & 0,14 & 4 & 0,56 \\
\hline Sistem manajemen informasi yang terintegrasi & $\mathrm{W}$ & 0,12 & 3 & 0,36 \\
\hline Sistem keuangan organisasi & $\mathrm{W}$ & 0,13 & 2 & 0,26 \\
\hline Kerjasama dengan pihak bank dan pemerintah & $\mathrm{W}$ & 0,13 & 2 & 0,26 \\
\hline Total & $\mathbf{1}$ & $\mathbf{3 , 0 4}$ \\
\hline
\end{tabular}

Matriks IFE merupakan matriks yang berasal dari faktor internal organisasi yang terdiri atas strength / kekuatan dan weakness/kelemahan. Dari hasil perhitungan didapatkan nilai 3,04. 
b. Matriks EFE

Matriks EFE digunakan untuk mengevaluasi faktor-faktor eksternal perusahaan. Data eksternal dikumpulkan untuk menganalisa hal-hal menyangkut persoalan ekonomi, sosial, budaya, lingkungan, politik, pemerintahan, hukum, teknologi, persaingan di pasar industri di mana perusahaan berada. Hal ini penting karena faktor eksternal berpengaruh secara langsung maupun tidak langsung terhadap perusahaan. Adapun analisis menggunakan matriks EFE dapat dilihat pada Tabel 7 sebagai berikut.

Tabel 7. Analisis Matriks EFE

\begin{tabular}{|l|c|c|c|c|}
\hline \multicolumn{1}{|c|}{ Faktor Eksternal } & O/T & Bobot & Rating & Nilai \\
\hline Stabilitas politik & $\mathrm{O}$ & 0,15 & 3 & 0,45 \\
\hline Pertumbuhan penduduk & $\mathrm{O}$ & 0,16 & 3 & 0,48 \\
\hline Kondisi geografis & $\mathrm{O}$ & 0,13 & 2 & 0,26 \\
\hline Adat istiadat masyarakat & $\mathrm{T}$ & 0,14 & 2 & 0,28 \\
\hline Pengembalian konsinyasi & $\mathrm{T}$ & 0,15 & 3 & 0,45 \\
\hline Pendapatan tol & $\mathrm{T}$ & 0,16 & 2 & 0,32 \\
\hline Cuaca & $\mathrm{T}$ & 0,11 & 2 & 0,22 \\
\hline Total & & $\mathbf{1}$ & $\mathbf{2 , 4 6}$ \\
\hline
\end{tabular}

Matriks EFE merupakan matriks yang berasal dari faktor eksternal organisasi yang terdiri atas Opportunities/peluang dan Threat/Ancaman. Dari hasil perhitungan didapatkan nilai 2.46 .

\section{$\underline{\text { Analisis QSPM }}$}

Teknik ini secara objektif menunjukkan strategi mana yang terbaik. QSPM menggunakan analisis dari input dan hasil pencocokan untuk secara objektif menentukan strategi yang hendak dijalankan di antara strategi-strategi alternatif. Secara konseptual QSPM menentukan daya tarik dari berbagai strategi yang dibangun berdasarkan faktor-faktor keberhasilan penting internal dan eksternal. Daya tarik relatif dari tiap strategi di dalam serangkaian alternatif dihitung dengan menentukan dampak kumulatif dari setiap faktor keberhasilan penting internal dan eksternal. Adapun analisis menggunakan QSPM dapat dilihat pada Tabel 8 sebagai berikut. 
Tabel 8. Analisis QSPM

\begin{tabular}{|c|c|c|c|c|c|c|c|}
\hline \multirow{4}{*}{ Faktor Kunci } & \multirow{4}{*}{ Bobot } & \multicolumn{6}{|c|}{ Alternatif Strategi } \\
\hline & & \multirow{2}{*}{\multicolumn{2}{|c|}{$\begin{array}{c}1 \\
\text { Meningkatkan } \\
\text { pendapatan bisnis } \\
\text { jalan tol }\end{array}$}} & \multirow{2}{*}{\multicolumn{2}{|c|}{$\begin{array}{c}2 \\
\text { Meningkatkan } \\
\text { pendapatan melalui } \\
\text { bisnis non jalan tol }\end{array}$}} & \multirow{2}{*}{\multicolumn{2}{|c|}{$\begin{array}{c}3 \\
\text { Melakukan } \\
\text { alternatif } \\
\text { pendanaan ulang }\end{array}$}} \\
\hline & & & & & & & \\
\hline & & AS & TAS & AS & TAS & AS & TAS \\
\hline \multicolumn{8}{|l|}{ Opportunities } \\
\hline Stabilitas politik & 0,15 & 3 & 0,45 & 4 & 0,6 & 3 & 0,45 \\
\hline Pertumbuhan penduduk & 0,16 & 4 & 0,64 & 4 & 0,64 & 3 & 0,48 \\
\hline Kondisi geografis & 0,13 & 2 & 0,26 & 3 & 0,39 & 2 & 0,26 \\
\hline \multicolumn{8}{|l|}{ Threat } \\
\hline Adat istiadat masyarakat & 0,14 & 2 & 0,28 & 4 & 0,56 & 2 & 0,28 \\
\hline $\begin{array}{l}\text { Pengembalian } \\
\text { konsinyasi }\end{array}$ & 0,15 & 2 & 0,3 & 2 & 0,3 & 2 & 0,3 \\
\hline Pendapatan tol & 0,16 & 2 & 0,32 & 4 & 0,64 & 3 & 0,48 \\
\hline Cuaca & 0,11 & 2 & 0,22 & 2 & 0,22 & 2 & 0,22 \\
\hline Total & 1 & & & & & & \\
\hline \multicolumn{8}{|l|}{ Strength } \\
\hline SDM yang kompetitif & 0,16 & 3 & 0,48 & 4 & 0,64 & 3 & 0,48 \\
\hline $\begin{array}{l}\text { Organisasi yang } \\
\text { kondusif }\end{array}$ & 0,16 & 4 & 0,64 & 4 & 0,64 & 4 & 0,64 \\
\hline $\begin{array}{l}\text { Monitoring dan evaluasi } \\
\text { intern pekerjaan }\end{array}$ & 0,16 & 4 & 0,64 & 3 & 0,48 & 4 & 0,64 \\
\hline Budaya kerja & 0,14 & 4 & 0,56 & 4 & 0,56 & 4 & 0,56 \\
\hline \multicolumn{8}{|l|}{ Weakness } \\
\hline $\begin{array}{l}\text { Sistem manajemen } \\
\text { informasi yang } \\
\text { terintegrasi }\end{array}$ & 0,12 & 3 & 0,36 & 4 & 0,48 & 3 & 0,36 \\
\hline $\begin{array}{l}\text { Sistem keuangan } \\
\text { organisasi }\end{array}$ & 0,13 & 2 & 0,26 & 3 & 0,39 & 2 & 0,26 \\
\hline $\begin{array}{l}\text { Kerjasama dengan pihak } \\
\text { bank dan pemerintah }\end{array}$ & 0,13 & 2 & 0,26 & 3 & 0,39 & 4 & 0,52 \\
\hline Total & 1 & & 5,67 & & 6,93 & & 5,93 \\
\hline
\end{tabular}

Berdasarkan hasil Matriks QSPM diatas telah ditentukan tiga strategi yang masing masing memiliki peringkat dan dapat diterapkan sesuai dengan pilihannya. Hasil Analisis Strategis disampaiakn pada Tabel 9 sebagai berikut.

Tabel 9. Hasil Analisis Strategi

\begin{tabular}{|l|l|l|}
\hline Peringkat & Nama Strategi & Nilai \\
\hline Peringkat 1 & Meningkatkan pendapatan melalui bisnis non jalan tol & 6,93 \\
\hline Peringkat 2 & Melakukan alternatif pendanaan ulang & 5,93 \\
\hline Peringkat 3 & Meningkatkan pendapatan bisnis jalan tol & 5,67 \\
\hline
\end{tabular}

Perumusan Langkah Strategis

Dari hasil analisis didapatkan peringkat dalam penentuan strategi diantaranya peringkat 1 yaitu meningkatkan pendapatan melalui bisnis non jalan tol, dengan cara pemasangan pembangkit listrik tenaga surya telah direncanakan oleh perusahaan untuk memaksimalkan 
pemanfaatan aset yang ada. Listrik yang dihasilkan nantinya dapat digunakan untuk kebutuhan operasional jalan tol atau dijual kepada PLN. Dengan demikian, nilai aset infrastruktur dapat dimaksimalkan. Selain itu pemasangan reklame di sepanjang koridor jalan tol merupakan suatu langkah untuk memanfaatkan ruang sekaligus menambah pendapatan perusahaan melalui bisnis non jalan tol. Strategi di peringkat 2 adalah melakukan alternatif pendanaan ulang yaitu Pinjaman ulang kepada lembaga pemberi pinjaman yang saat ini sedang berjalan atau dengan lembaga pemberi pinjaman yang lain. Salah satu alternatif yang dapat dilakukan adalah merestrukturisasi hutang menjadi obligasi. Hal ini dikarenakan kupon obligasi masih lebih murah ketimbang bunga pinjaman korporasi yang dipatok bank. Selain itu, perusahaan bisa melakukan pendanaan ulang melalui obligasi meski jatuh tempo obligasi masih lama. Sedangkan strategi pada peringkat 3 adalah meningkatkan pendapatan bisnis jalan tol dengan cara membangun tempat istirahat dan destinasi wisata strategi ini dapat mempengaruhi pendapatan melalui dua cara yaitu pertama meningkatkan minat pengguna jalan untuk melewati jalan tol dengan membayar tarif tol, karena daya tarik tempat istirahat tersebut dan kedua adalah pengguna jalan yang berhenti di tempat istirahat tersebut dapat menyumbang pendapatan dari transaksi yang dilakukan di tempat istirahat. Selain itu strategi penambahan panjang ruas jalan tol, penambahan panjang jalan tol dari kondisi eksisting diharapkan dapat meningkatkan kendaraan yang melintas pada jalan tol karena penambahan panjang ruas jalan tol akan menambah simpul-simpul atau pusat-pusat kegiatan yang terhubung.

\section{KESIMPULAN}

Penelitian mengenai analisis kebutuhan pengembangan usaha dan strategi bagi Jalan Tol Bali Mandara menghasilkan beberapa kesimpulan pokok sebagai berikut.

- Strategi pokok pengembangan terdiri dari 3 yang disebutkan berikut ini, berurutan dari yang terbaik : meningkatkan pendapatan melalui bisnis non jalan tol, melakukan alternative pendanaan ulang, meningkatkan pendapatan bisnis jalan tol.

- Strategi peringkat pertama bisa direalisasikan dengan memasang pembangkit tenaga surya dan pemasangan reklame disepanjang jalan tol.

- Strategi peringkat kedua bias direalisasikan dengan merestrukturisasi hutang menjadi obligasi.

- Startegi peringkat ketiga bias direalisasikan dengan membangun rest area dan destinasi wisata di jaringan jalan tol.

Penelitian ini telah menumbuhkan rasa keinginan tahu tentang bisnis infrastruktur jalan tol, seperti misalnya : struktur pembiayaan dan pendapatan bisnis jalan tol, manfaat ekonomi bisnis jalan tol, dan yang lain.

\section{DAFTAR PUSTAKA}

Anwar, N. \& Supriyatna (2003). "Dasar Teori dan Pengembangan Aplikasi Manajemen Aset di Bidang Prasarana dan Sarana Publik". Buletin Pendidikan Profesional, Vol 1, No 5.

Clarence Valley Council (2007). Asset Management Strategy. Version 1.03, August 2007. Jeff Roorda \& Associates.

David, Fred (2008). Manajemen Strategik : Studi Pendekatan Keunggulan Bersaing. Edisi ke15. Penerbit Salemba Empat. Jakarta.

JBT (2018). Annual Report 2018. Jalan Bali Mandara Tol. Denpasar.

Jogiyanto (2005). Sistem Informasi Strategi Untuk Keunggulan Kompetitif. Penerbit Andi. Yogyakarta.

Karim, A.T. (2018). "Best Practice Pengusahaan Jalan Tol Bali Mandara, Manajemen Investasi dan Pengelolaan Jalan Tol". Handout Lecture: Seminar Nasional Penerapan 
Teknologi Infrastruktur Jalan dan Jembatan Dalam Meningkatkan Mutu dan Keselamatan Kerja. Jasa Marga Learning Institute.

BAPPENAS (2011). Masterplan Percepatan dan Perluasan Pembangunan Ekonomi Indonesia 2011-2025. Kementerian Koordinator Bidang Perekonomian dan BAPPENAS. Jakarta

PP 04/78. Peraturan Pemerintah Nomor 04 Tahun 1978 tentang Pendirian PT Jasa Marga.

PP 30/17. Peraturan Pemerintah Nomor 30 Tahun 2017 tentang Perubahan Ketiga Atas PP 15/2005 tentang Jalan Tol

PerMen PUPR 01/17. Peraturan Menteri Pekerjaan Umum dan Perumahan Rakyat 01/PRT/M/2017 tentang Tata Cara Pelaksanaan Pengadaan Badan Usaha Untuk Pengusahaan Jalan Tol

PerMen PUPR 06/18. Peraturan Menteri Pekerjaan Umum dan Perumahan Rakyat 06/PRT/M/2018 tentang Wewenang dan Tugas Direktorat Jenderal Bina Marga, Badan Pengatur Jalan Tol, dan Badan Usaha Jalan Tol Dalam Penyelenggaraan Jalan Tol.

KepMen Kimpraswil 353/01. Keputusan Menteri Permukiman dan Prasarana Wilayah Nomor 353/KPTS/M/2001 tentang Ketentuan Teknik, Tata Cara Pembangunan dan Pemeliharaan Jalan Tol.

KepMen Kimpraswil 354/01. Keputusan Menteri Permukiman dan Prasarana Wilayah Nomor 354/KPTS/M/2001 tentang Kegiatan Operasi Jalan Tol

Jasa Marga. (2018). Laporan Tahunan 2018 PT Jasa Marga (Persero). PT Jasa Marga. Jakarta.

Jasa Marga Bali (2018). Laporan Tahunan 2018 PT Jasa Marga Bali Tol. PT Jasa Marga Bali Tol. Denpasar.

Robbins, Stephen, P \& Judge. (2007). Perilaku Organisasi. Edisi ke-12. Penerbit Salemba Empat. Jakarta.

Suprayitno, H. dan Soemitro, R.A.A. (2018). "Preliminary Reflexion on Basic Principle of Infrastructure Asset Management". Jurnal Manajemen Aset Infrastruktur \& Fasilitas, Vol. 2, No. 1, Maret 2018, hal : 1-9.

Sutedi, Adrian (2012). Tinjauan Yuridis Letter of Credit dan Kredit Sindikasi. Penerbit Alfabeta. Bandung

Wareza, M. (2018). "Bunga Bank Tinggi, Perusahaan Cenderung Pilih Obligasi". https://www.cnbcindonesia.com/market/20180921135446-17-34208/bunga-bank-tinggiperusahaan-cenderung-pilih-obligasi. 